\title{
Effect of Microbiological Properties, Yield Attributes and Yield of Rainfed Maize (Zea mays L.) Influenced Different Methods of Organic Sources
}

\author{
K.P. Suresh Naik ${ }^{1}$, A.H. Kumar Naik ${ }^{1 *}$ and T. Basavaraj Naik ${ }^{2}$ \\ ${ }^{1}$ AICRP on Castor \& Groundnut, ZAHRS, Hiriyur, Karnataka, India \\ ${ }^{2}$ (Agronomy), UAHS, Navile, Shivamogga-577225, Karnataka, India \\ *Corresponding author
}

\section{A B S T R A C T}

\begin{tabular}{l} 
K e y w o r d s \\
$\begin{array}{l}\text { Microbial population, } \\
\text { Biodigester liquid } \\
\text { manure, Farmyard } \\
\text { manure, Organic } \\
\text { farming, Rainfed } \\
\text { maize. }\end{array}$ \\
\hline Article Info \\
$\begin{array}{l}\text { Accepted: } \\
\text { 26 September } 2017 \\
\text { Available Online: } \\
10 \text { November } 2017\end{array}$ \\
\hline
\end{tabular}

A field experiment was conducted during kharif 2010 under rainfed condition on red sandy loam soil to study the "Effect of farmyard manure and Biodigester liquid manure on soil microbial population and yield of rainfed maize (Zea mays L.)" at Agricultural Research Station, University of Agricultural Sciences (Bangalore), Bhavikere, Tarikere taluk. The experiment was laid out in randomised complete block design with three replications. There were totally 13 treatment combinations comprasing of different levels farmyard manure $\left(7.5,10\right.$ and $\left.12.5 \mathrm{t} \mathrm{ha}^{-1}\right)$ and Biodigester liquid manure equivalent $(75,100,125$ and $150 \mathrm{~kg} \mathrm{~N} \mathrm{ha}^{-1}$ ) compared with control (FYM $7.5 \mathrm{t} \mathrm{ha}^{-1}+$ RDF: 100:50:25 kg NPK $\left.\mathrm{ha}^{-1}\right)$. Application of $12.5 \mathrm{t} \mathrm{ha}^{-1} \mathrm{FYM}+$ biodegester liquid manure equivalent at $150 \mathrm{~kg} \mathrm{~N}$ $\mathrm{ha}^{-1}$ recorded significantly higher microbial population in soil after the crop harvest $(50.5 \times$ $10^{6} \mathrm{CFU} \mathrm{g} \mathrm{g}^{-1}, 26.0 \times 10^{4} \mathrm{CFU} \mathrm{g} \mathrm{g}^{-1}, 23.8 \times 10^{3} \mathrm{CFU} \mathrm{\textrm {g } ^ { - 1 }}$ of total bacteria, fungi and actinomycetes, respectively), grain yield $\left(56.2 \mathrm{q} \mathrm{ha}^{-1}\right)$ and straw yield $\left(108.9 \mathrm{q} \mathrm{ha}^{-1}\right)$ compared with remaining treatments and recorded lower microbial population with application of FYM @7.5 tha ${ }^{-1}+$ biodigester liquid manure equivalent @ $75 \mathrm{~kg} \mathrm{~N}$ ha ${ }^{-1}$ $\left(32.3 \times 10^{6} \mathrm{CFU} \mathrm{g}{ }^{-1}, 13.8 \times 10^{4} \mathrm{CFU} \mathrm{g}^{-1}, 9.5 \times 10^{3} \mathrm{CFU} \mathrm{g}{ }^{-1}\right.$, of total bacteria, fungi and actinomycetes, respectively), grain yield $\left(42.2 \mathrm{q} \mathrm{ha}^{-1}\right)$ and straw yield $\left(85.4 \mathrm{q} \mathrm{ha}^{-1}\right)$.

\section{Introduction}

Maize (Zea mays L.) is the third most important staple food crop of the world next to wheat and rice. Maize is important cereal because of its great production potential and adaptability to wide range of environments. Maize occupies prime place in Indian economy, like rice, wheat and millets. In India, maize is grown in an area of $8.27 \mathrm{~m}$ ha with an annual production of about $17.30 \mathrm{~m} \mathrm{t}$. The average productivity of maize in India is about $2091 \mathrm{~kg} \mathrm{ha}^{-1}$. In Karnataka maize is grown in an area of $0.93 \mathrm{~m}$ ha producing 2.63 $\mathrm{m} \mathrm{t}$ with a productivity of $2970 \mathrm{Kg} \mathrm{ha}^{-1}$
(Anon., 2010). Now, the agricultural research is focused on evolving ecologically sound, biologically sustainable and socioeconomically viable technologies so application of Farmyard manure (FYM) to the crops is being practiced since time immemorial. Addition of well decomposed farm yard manure to the soil besides supplying plant nutrients, it also acts as binding material and improves the physical, chemical and biological properties of soil. Similarly, application of biodigester liquid manure will increase the microbial 
population's viz., nitrogen fixers, phosphorus solubalizing bacteria and actinomycetes. Hence, in recent years the potentiality of FYM and biodigester liquid to supply nutrients and enhance beneficial microbes for faster decomposition is being recognized widely in field crops. The essence of practicing organic farming lies in the use of naturally available resources like organic wastes, predators, parasites in conjunction with natural processes like decomposition, biological fixation and resistance to achieve the needs of crop production. Most of natural resources are useful only after they are microbiologically transformed to release the nutrients. Hence, organic farming is successful only when microbial population proliferates under suitable condition. Hence, there is an urgent need for a fresh look to exploit the organic farming approaches by making use of locally available organic sources of nutrients for growing maize without using chemical fertilizers, which maintains long term soil fertility and minimizes environmental hazards. Hence, in recent years the potentiality of FYM and biodigester liquid to supply nutrients and enhance beneficial microbes for faster decomposition is being recognized widely in field crops.

\section{Materials and Methods}

A Field experiment entitled as Effect of farmyard manure and biodigester liquid manure on growth and yield of rainfed maize (Zea mays L.)" conducted during the Kharif 2010 at Agricultural Research Station, University of Agricultural Sciences (Bangalore), Bhavikere, Tarikere taluk, Chikkamagalure Dist. Karnataka. The soil of the experimental site was red sandy loam. The organic carbon content was 0.45 per cent. The available nitrogen was low (268.6 kg ha-1), phosphorus was medium (23.6 kg ha-1) and potassium $\left(154.5 \mathrm{~kg} \mathrm{ha}^{-1}\right)$ was medium. The experiment was laid out in Randomised complete block design (RCBD) with 13 treatments and three replications with maize hybrid Nithyashree (NAH-2049). The treatments includes $\mathrm{T}_{1}=\mathrm{FYM}$ at $7.5 \mathrm{t} \mathrm{ha}^{-1}$ as a basal dose + BDLME at $75 \mathrm{~kg} \mathrm{~N} \mathrm{ha}^{-1}, \mathrm{~T}_{2}$ $=$ FYM at $7.5 \mathrm{t} \mathrm{ha}^{-1}$ as a basal dose + BDLME at $100 \mathrm{~kg} \mathrm{~N} \mathrm{ha}^{-1}, \mathrm{~T}_{3}=\mathrm{FYM}$ at $7.5 \mathrm{t} \mathrm{ha}^{-1}$ as a basal dose + BDLME at $125 \mathrm{~kg} \mathrm{~N}^{-1}, \mathrm{~T}_{4}$ $=$ FYM at $7.5 \mathrm{t} \mathrm{ha}^{-1}$ as a basal dose + BDLME at $150 \mathrm{~kg} \mathrm{~N} \mathrm{ha}^{-1}, \mathrm{~T}_{5}=\mathrm{FYM}$ at $10 \mathrm{t} \mathrm{ha}^{-1}$ as a basal dose + BDLME at $75 \mathrm{~kg} \mathrm{~N} \mathrm{ha}^{-1}, \mathrm{~T}_{6}$ $=\mathrm{FYM}$ at $10 \mathrm{t} \mathrm{ha}^{-1}$ as a basal dose + BDLME at $100 \mathrm{~kg} \mathrm{~N} \mathrm{ha}^{-1}, \mathrm{~T}_{7}=\mathrm{FYM}$ at $10 \mathrm{t} \mathrm{ha}^{-1}$ as a basal dose + BDLME at $125 \mathrm{~kg} \mathrm{~N}$ ha $^{-1}, \mathrm{~T}_{8}=$ FYM at $10 \mathrm{t} \mathrm{ha}^{-1}$ as a basal dose + BDLME at $150 \mathrm{~kg} \mathrm{~N} \mathrm{ha}^{-1}, \mathrm{~T}_{9}=\mathrm{FYM}$ at $12.5 \mathrm{t} \mathrm{ha}^{-1}$ as a basal dose + BDLME at $75 \mathrm{~kg} \mathrm{~N} \mathrm{ha}^{-1}, \mathrm{~T}_{10}$ $=$ FYM at $12.5 \mathrm{t} \mathrm{ha}^{-1}$ as a basal dose + BDLME at $100 \mathrm{~kg} \mathrm{~N} \mathrm{ha}^{-1}, \mathrm{~T}_{11}=\mathrm{FYM}$ at $12.5 \mathrm{t}$ $\mathrm{ha}^{-1}$ as a basal dose + BDLME at $125 \mathrm{~kg} \mathrm{~N}^{-}$ ${ }^{1}, \mathrm{~T}_{12}=\mathrm{FYM}$ at $12.5 \mathrm{t} \mathrm{ha}^{-1}$ as a basal dose + BDLME at $150 \mathrm{~kg} \mathrm{~N} \mathrm{ha}^{-1}$ and $\mathrm{T}_{13}=$ Control (FYM $7.5 \mathrm{t} \mathrm{ha}^{-1}+$ RDF: 100:50:25 kg NPK $\left.\mathrm{ha}^{-1}\right)$.

\section{Procedure of preparation of biodigester liquid}

Soil was excavated from $10 \mathrm{~m} \times 5 \mathrm{~m} \times 1 \mathrm{~m}$ (length $\times$ width $\times$ height) dimension for creation of a pit. Later on it was constructed in to a tank using reinforced cement concrete for the floor and brick and mortar for walls. Slope of the floor was given in two directions for facilitating the collection of liquid manure in the collection pit. Cattle shed washings and other liquid organic wastes are collected in the biodigestor tank. Crop residues like husk, cob sheaths, haulms, earheads, pith, straws, coconut fronds etc., along with the weeds are allowed to digest along with the cattle shed washings, cattle urine and some quantity of dung. Water is allowed just to reduce the volatalisation losses from biodigester liquid. The liquid residue is collected in the bottom 
corner side of the biodigester tank. The collected liquid residue manure is used for application in the field.

Well decomposed farmyard manure was incorporated three weeks prior to sowing and prior to application of biodigester liquid manure was analyzed for its nitrogen content. On the basis of nitrogen content, required quantity of biodigester liquid with 1:4 dilutions (Biodigester: water) was applied to all treatments except $\mathrm{T}_{13}$ treatment (RDF). Biodigester liquid was applied to the soil in open furrows $10 \mathrm{~cm}$ away from crop row and applied in treatments for two times ie., at 30 and 45 days after sowing (DAS).

Prior to application, biodigester liquid manure was analyzed for its nitrogen content. On the basis of nitrogen content, required quantity of biodigester liquid with 1:4 dilutions (Biodigester: water) was applied to all treatments except $\mathrm{T}_{13}$ treatment (RDF). Biodigester liquid was applied to the soil in open furrows $10 \mathrm{~cm}$ away from crop row. Biodigester liquid was applied in treatments for two times i.e., at 30 and 45 days after sowing (DAS).

\section{Microbial analysis of the soil sample before and after the crop harvest}

The microbial population in the soil after harvest of the crop was determined by serial dilution plate count method. Soil samples from different treatments were collected separately replication wise and then they were pooled. Ten grams of pooled soil (treatment wise) was mixed in $90 \mathrm{ml}$ sterilized water blank to give $10^{-1}$ dilutions. Subsequent dilutions up to $10^{6}$ were made by transferring serially one $\mathrm{ml}$ of each dilution to nine $\mathrm{ml}$ sterilized water blanks. The population of total bacteria, fungi and actinomycetes were estimated by serial dilution plate count technique and by plating on appropriate media viz., soil extract agar, Martins Rose Bengal Streptomycin sulphate agar and Kustras agar, respectively. The inoculated plates were kept for incubation at $30^{\circ} \mathrm{C} \pm 1^{\circ} \mathrm{C}$ for a week and emerged colonies were counted.

\section{Results and Discussion}

Among the different treatments, significantly higher number of microbial population registered in application of FYM @ 12.5 t $\mathrm{ha}^{-1}+$ biodigester liquid manure equivalent @ $150 \mathrm{~kg} \mathrm{~N} \mathrm{ha}^{-1}\left(50.0 \times 10^{6} \mathrm{CFU} \mathrm{g}^{-1}, 26.0 \times 10^{4}\right.$ $\mathrm{CFU} \mathrm{g}{ }^{-1}, 23.8 \times 10^{3} \mathrm{CFU} \mathrm{g}^{-1}$ of total bacteria, fungi, actinomycetes, respectively) (Table 1) and grain yield (56.2 $\mathrm{q} \mathrm{ha}^{-1}$ ) and straw yield (108.9 q ha ${ }^{-1}$ ) (Table 2) due to application of FYM and biodigester liquid manure which might have improved activity of beneficial micro-organisms and also due to increase in the organic carbon besides increasing the availability of NPK in soil and Higher grain weight of rainfed maize was mainly attributed to higher leaf area and dry matter accumulation in leaves which might have supplied required photosynthates to the reproductive parts more precisely to the seed. Thus, due to availability of photosynthates the seed might have developed fully and resulted in bolder seeds and hence recorded higher grain weight. These results are in accordance with Sharma and Dixit (1987), Kandeler et al., (1999) and Ravikumar (2009). It was on par with application of FYM @ $10 \mathrm{t} \mathrm{ha}^{-1}+$ biodigester liquid manure equivalent @ 150 $\mathrm{kg} \mathrm{N} \mathrm{ha}{ }^{-1}\left(48.1 \times 10^{6} \mathrm{CFU} \mathrm{g}^{-1}, 23.9 \times 10^{4}\right.$ CFU g ${ }^{-1}, 22.3 \times 10^{3} \mathrm{CFU} \mathrm{g}^{-1}$, of total bacteria, fungi and actinomycetes, respectively) with grain yield (55.1 q ha ${ }^{-1}$ ), straw yield (107.0 q $\mathrm{ha}^{-1}$ ) and the application of FYM @ $7.5 \mathrm{tha}^{-1}$ $+100: 05: 25 \mathrm{~kg} \mathrm{NPK} \mathrm{ha}^{-1}$ recorded grain yield $\left(54.2 \mathrm{q} \mathrm{ha}^{-1}\right)$, straw yield (105.7 q ha $\left.\mathrm{q}^{-1}\right)$ and $\left(46.8 \times 10^{6} \mathrm{CFU} \mathrm{g}^{-1}, 22.8 \times 10^{4} \mathrm{CFU} \mathrm{g}^{-1}, 20.9\right.$ $\times 10^{3} \mathrm{CFU} \mathrm{\textrm {g } ^ { - 1 }}$, of total bacteria, fungi and actinomycetes, respectively). 
Table.1 Microbial population (initial and after harvest) and grain yield of maize as influenced by different levels of FYM and biodigester liquid manure under rainfed condition

\begin{tabular}{|c|c|c|c|}
\hline Treatments & $\begin{array}{l}\text { Bacteria } \\
\left(\mathrm{No.} \times 10^{6}\right. \\
\left.\text { CFU } \mathbf{g}^{-1}\right)\end{array}$ & $\begin{array}{c}\text { Fungi } \\
\left(\text { No. } \times 10^{4}\right. \\
\left.\text { CFU g }{ }^{-1}\right)\end{array}$ & $\begin{array}{l}\text { Actinomycetes } \\
\left(\text { No. } \times \mathbf{1 0}^{\mathbf{3}}\right. \\
\left.\text { CFU g } \mathbf{g}^{-1}\right)\end{array}$ \\
\hline $\mathrm{T}_{1}$ : FYM at $7.5 \mathrm{t} \mathrm{ha}^{-1}+\mathrm{BDLME}$ at $75 \mathrm{~kg} \mathrm{~N} \mathrm{ha}^{-1}$ & 32.3 & 13.8 & 9.5 \\
\hline $\mathrm{T}_{2}: \mathrm{FYM}$ at $7.5 \mathrm{t} \mathrm{ha}^{-1}+\mathrm{BDLME}$ at $100 \mathrm{~kg} \mathrm{~N}^{-1}$ & 33.2 & 14.3 & 10.7 \\
\hline $\mathrm{T}_{3}: \mathrm{FYM}$ at $7.5 \mathrm{t} \mathrm{ha}^{-1}+\mathrm{BDLME}$ at $125 \mathrm{~kg} \mathrm{~N} \mathrm{ha}^{-1}$ & 35.0 & 15.3 & 11.8 \\
\hline $\mathrm{T}_{4}: \mathrm{FYM}$ at $7.5 \mathrm{t} \mathrm{ha}^{-1}+\mathrm{BDLME}$ at $150 \mathrm{~kg} \mathrm{~N} \mathrm{ha}^{-1}$ & 42.3 & 16.7 & 15.2 \\
\hline $\mathrm{T}_{5}: \mathrm{FYM}$ at $10 \mathrm{t} \mathrm{ha}^{-1}+\mathrm{BDLME}$ at $75 \mathrm{~kg} \mathrm{~N} \mathrm{ha}^{-1}$ & 34.7 & 14.7 & 11.7 \\
\hline $\mathrm{T}_{6}:$ FYM at $10 \mathrm{tha}^{-1}+\mathrm{BDLME}$ at $100 \mathrm{~kg} \mathrm{~N} \mathrm{ha}^{-1}$ & 36.2 & 15.5 & 11.6 \\
\hline $\mathrm{T}_{7}: \mathrm{FYM}$ at $10 \mathrm{tha}^{-1}+\mathrm{BDLME}$ at $125 \mathrm{~kg} \mathrm{~N} \mathrm{ha}^{-1}$ & 37.8 & 18.8 & 15.5 \\
\hline $\mathrm{T}_{8}: \mathrm{FYM}$ at $10 \mathrm{t} \mathrm{ha}^{-1}+\mathrm{BDLME}$ at $150 \mathrm{~kg} \mathrm{~N} \mathrm{ha}^{-1}$ & 48.1 & 23.9 & 22.3 \\
\hline $\mathrm{T}_{9}$ : FYM at $12.5 \mathrm{t} \mathrm{ha}^{-1}+$ BDLME at $75 \mathrm{~kg} \mathrm{~N} \mathrm{ha}^{-1}$ & 36.7 & 16.0 & 15.0 \\
\hline $\mathrm{T}_{10}: \mathrm{FYM}$ at $12.5 \mathrm{t} \mathrm{ha}^{-1}+\mathrm{BDLME}$ at $100 \mathrm{~kg} \mathrm{~N} \mathrm{ha}^{-1}$ & 40.5 & 17.8 & 16.8 \\
\hline $\mathrm{T}_{11}: \mathrm{FYM}$ at $12.5 \mathrm{t} \mathrm{ha}^{-1}+\mathrm{BDLME}$ at $125 \mathrm{~kg} \mathrm{~N} \mathrm{ha}^{-1}$ & 41.3 & 19.3 & 17.2 \\
\hline $\mathrm{T}_{12}: \mathrm{FYM}$ at $12.5 \mathrm{t} \mathrm{ha}^{-1}+\mathrm{BDLME}$ at $150 \mathrm{~kg} \mathrm{~N}^{-1}$ & 50.5 & 26.0 & 23.8 \\
\hline $\mathrm{T}_{13}:$ Control (FYM $\left.7.5 \mathrm{t} \mathrm{ha}^{-1}+\mathrm{RDF}: 100: 50: 25 \mathrm{~kg} \mathrm{NPK} \mathrm{ha}^{-1}\right)$ & 46.8 & 22.8 & 20.9 \\
\hline S.Em \pm & 1.65 & 1.98 & 1.05 \\
\hline C.D. at $5 \%$ & 4.87 & 5.86 & 3.11 \\
\hline Initial population & 31.3 & 18.4 & 14.8 \\
\hline
\end{tabular}

FYM: Farmyard manure, BDLME: Biodigester liquid manure equivalent

Table. 2 Grain yield, stover yield and harvest index of maize as influenced by different levels of Farmyard manure and biodigester liquid manure under rainfed condition

\begin{tabular}{|c|c|c|}
\hline Treatments & $\begin{array}{l}\text { Grain yield } \\
\left(\mathrm{q} \mathrm{ha}^{-1}\right)\end{array}$ & $\begin{array}{l}\text { Stover yield } \\
\quad\left(\mathrm{q} \mathrm{ha}^{-1}\right)\end{array}$ \\
\hline $\mathrm{T}_{1}: \mathrm{FYM}$ at $7.5 \mathrm{t} \mathrm{ha}^{-1}+\mathrm{BDLME}$ at $75 \mathrm{~kg} \mathrm{~N} \mathrm{ha}^{-1}$ & 42.2 & 85.4 \\
\hline $\mathrm{T}_{2}:$ FYM at $7.5 \mathrm{t} \mathrm{ha}^{-1}+\mathrm{BDLME}$ at $100 \mathrm{~kg} \mathrm{~N} \mathrm{ha}^{-1}$ & 42.6 & 87.0 \\
\hline $\mathrm{T}_{3}:$ FYM at $7.5 \mathrm{t} \mathrm{ha}^{-1}+\mathrm{BDLME}$ at $125 \mathrm{~kg} \mathrm{~N} \mathrm{ha}^{-1}$ & 44.0 & 90.9 \\
\hline $\mathrm{T}_{4}: \mathrm{FYM}$ at $7.5 \mathrm{t} \mathrm{ha}^{-1}+\mathrm{BDLME}$ at $150 \mathrm{~kg} \mathrm{~N} \mathrm{ha}^{-1}$ & 46.2 & 97.0 \\
\hline $\mathrm{T}_{5}:$ FYM at $10 \mathrm{t} \mathrm{ha}^{-1}+$ BDLME at $75 \mathrm{~kg} \mathrm{~N} \mathrm{ha}^{-1}$ & 43.3 & 88.4 \\
\hline $\mathrm{T}_{6}: \mathrm{FYM}$ at $10 \mathrm{tha}^{-1}+\mathrm{BDLME}$ at $100 \mathrm{~kg} \mathrm{~N} \mathrm{ha}^{-1}$ & 44.7 & 93.8 \\
\hline $\mathrm{T}_{7}: \mathrm{FYM}$ at $10 \mathrm{t} \mathrm{ha}^{-1}+\mathrm{BDLME}$ at $125 \mathrm{~kg} \mathrm{~N} \mathrm{ha}^{-1}$ & 46.9 & 97.0 \\
\hline $\mathrm{T}_{8}: \mathrm{FYM}$ at $10 \mathrm{tha}^{-1}+\mathrm{BDLME}$ at $150 \mathrm{~kg} \mathrm{~N} \mathrm{ha}^{-1}$ & 55.1 & 107.0 \\
\hline $\mathrm{T}_{9}:$ FYM at $12.5 \mathrm{t} \mathrm{ha}^{-1}+$ BDLME at $75 \mathrm{~kg} \mathrm{~N} \mathrm{ha}^{-1}$ & 45.2 & 94.9 \\
\hline $\mathrm{T}_{10}: \mathrm{FYM}$ at $12.5 \mathrm{t} \mathrm{ha}^{-1}+\mathrm{BDLME}$ at $100 \mathrm{~kg} \mathrm{~N} \mathrm{ha}^{-1}$ & 48.0 & 99.5 \\
\hline $\mathrm{T}_{11}: \mathrm{FYM}$ at $12.5 \mathrm{t} \mathrm{ha}^{-1}+\mathrm{BDLME}$ at $125 \mathrm{~kg} \mathrm{~N} \mathrm{ha}^{-1}$ & 50.0 & 100.7 \\
\hline $\mathrm{T}_{12}: \mathrm{FYM}$ at $12.5 \mathrm{t} \mathrm{ha}^{-1}+\mathrm{BDLME}$ at $150 \mathrm{~kg} \mathrm{~N} \mathrm{ha}^{-1}$ & 56.2 & 108.9 \\
\hline $\mathrm{T}_{13}:$ Control (FYM $7.5 \mathrm{t} \mathrm{ha}^{-1}+$ RDF: $100: 50: 25 \mathrm{~kg} \mathrm{NPK} \mathrm{ha}^{-1}$ ) & 54.2 & 105.7 \\
\hline S.Em \pm & 1.42 & 1.17 \\
\hline C.D. at $5 \%$ & 4.21 & 3.45 \\
\hline
\end{tabular}

FYM: Farmyard manure, BDLME: Biodigester liquid manure equivalent 
Lower microbial populations, grain yield and straw yield was recorded with application of FYM @ $7.5 \mathrm{t} \mathrm{ha}^{-1}+$ biodigester liquid manure equivalent@75 kg N ha ${ }^{-1}\left(32.3 \times 10^{6} \mathrm{CFU} \mathrm{g}^{-}\right.$ ${ }^{1}, 13.8 \times 10^{4} \mathrm{CFU} \mathrm{g}^{-1}, 9.5 \times 10^{3} \mathrm{CFU} \mathrm{g}^{-1}$, of total bacteria, fungi and actinomycetes, respectively), (42.2 $\left.\mathrm{q} \mathrm{ha}^{-1}\right)$ and (85.4 $\left.\mathrm{q} \mathrm{ha}^{-1}\right)$ due lower availability of organic matter and favorable condition in the soil which resulted in lesser microbial activity, this findings similar with Badole and More (2001) and Naveenkumar, (2009).

\section{Acknowledgement}

I am thankful to the Directorate of Research, University of Agricultural Sciences, UAS, GKVK, Bangaluru for providing me an financial assistance to carry out my research work under RKVY Project scheme. I am personally thankful to Dr. Basavaraj Naik, T helped me to conducting this research work.

\section{References}

Anonymous, 2010, Annual Report, published by Department of Agriculture and Cooperation, GOI, New Delhi.

Badole, S. B. and More, S.D., 2001, Residual effect of integrated nutrient management on yield of groundnut. $J$. Maharashtra., 26 (1): 109-110.

Kandeler, E., Michael Stemmer and Eva Mariaklicmanek, 1999, Response of soil microbial biomass, urease and xylanase within particle size fractions to longterm soil management. Soil Biol. Biochem., 31 (2): 261-273.

Naveenkumar, A, T., 2009, Effect of FYM and Biodigested liquid manure on growth and yield of groundnut under rainfed condition, M.Sc. (Agri.) Thesis submitted to Univ. Agric. Sci. Bangalore, Karnataka, India.

Ravikumar, H. S., 2009, Effect of FYM and Biodigested liquid manure on growth and yield of groundnut under rainfed condition. M. Sc. (Agri.) Thesis, Univ.Agric.Sci, Bangalore.

Sharma and Dixit, B. K., 1987, Effect of nutrient application on rainfed soybean. J. Indian Soc. Soil Sci., 35(3): 452:455.

\section{How to cite this article:}

Suresh Naik, K.P., A.H. Kumar Naik and Basavaraj Naik, T. 2017. Effect of Microbiological Properties, Yield Attributes and Yield of Rainfed Maize (Zea mays L.) Influenced Different Methods of Organic Sources. Int.J.Curr.Microbiol.App.Sci. 6(11): 3415-3419. doi: https://doi.org/10.20546/ijcmas.2017.611.401 